DOI https://doi.org/10.30525/978-9934-26-038-4-36

\title{
ІНАКТИВАЦІЯ МІКРОФЛОРИ ІНФІКОВАНИХ КОРЕНЕВИХ КАНАЛІВ У ХВОРИХ НА ЕНДОДОНТИЧНУ ПАТОЛОГІЮ
}

\author{
Синиця В. В. \\ кандидат медичних наук, \\ доцент кафедри терапевтичної стоматології \\ Львівський національний медичний університет \\ імені Данила Галицького \\ Довганик В. В. \\ кандидат медичних наук, \\ доцент кафедри терапевтичної стоматології \\ Львівський національний медичний університет \\ імені Данила Галищького \\ Гриновець В. С. \\ кандидат медичних наук, \\ дочент кафедри терапевтичної стоматології \\ Львівський національний медичний університет \\ імені Данила Галищького \\ м. Львів, Україна
}

Ефективність якісного ендодонтичного лікування залежить від того, наскільки повноцінно проведено три основні етапи лікування: інструментальну обробку кореневих каналів, медикаментний вплив на їхній вміст та обтурацію кореневого каналу (а по можливості - i його бічних та біляверхівкових дельтовидних розгалужень). В арсеналі сучасної ендодонтії ефективні технології механічного опрацювання кореневого каналу з використанням великої кількості різноманітних систем. Це ж стосується і методик пломбування кореневого каналу $[1,2,3,4]$. Окрім цього у стоматологів жодних сумнівів не викликає важливість хімічної обробки вмісту кореневого каналу та мікроканальців, а також вплив на уражені періапікальні тканини із використанням цілого арсеналу медикаментів $[1,2,4,5]$.

При проведенні ендодонтичного лікування стоматолог повинен вирішити наступні завдання:

1. Очищення та дезінфекція кореневого каналу для видалення тканин пульпи, мікроорганізмів і продуктів їх життєдіяльності.

2. Препарування кореневого каналу з механічним видаленням інфікованого дентину. 
3. Тривимірна обтурація системи кореневого каналу і створення біологічного бар'єра для запобігання реінфікування.

Основним етіологічним фактором ендодонтичних ускладнень карієсу $€$ патогенні мікроорганізми. Цим пояснюється широке використання різноманітних антимікробних речовин для лікування хворих 3 ендодонтичною патологією, особливо, якщо кореневі канали сильно інфіковані. Однак, значна кількість рецидивів i, зокрема, хронічних верхівкових періодонтитів вимагає нових методів пролонгованого впливу на мікрофлору кореневих каналів для їх максимальної дезінфекції.

Адже, якщо для проведення адекватного механічного опрацювання стінок кореневого каналу, медикаментної обробки каналу та його обтурації розроблено достатню кількість різноманітних схем і алгоритмів роботи, то вибору схем лікування, в залежності від стану тканин кореневого каналу, верхівкового, а також маргінального періодонту в ендодонтії приділено недостатньо уваги $[1,3,5]$.

Таким чином, з метою оптимізації механічної та медикаментної передпломбувальної обробки кореневих каналів, а також адекватного їх пломбування доцільно розробити відповідні алгоритми та протоколи проведення такого лікування. За основний критерій вибору схеми ендодонтичного лікування слід обрати ступінь інфікування кореневих каналів та ураження стінок кореневого каналу, стан тканин верхівкового періодонту, а також стан маргінального пародонту, наявність чи відсутність його ураження та ступінь такого ураження.

Запальний процес в періодонті розвивається внаслідок некрозу пульпи й обумовлений надходженням інфекційно-токсичного вмісту кореневих каналів через верхівковий отвір. Встановлено, що основне джерело інфекції при хронічному періодонтиті знаходиться не в періапікальній зоні, а в кореневому каналі $[3,6]$. Токсини, які викликають запальний процес в апікальній частині періодонта, - це, насамперед, мікробні ендотоксини та токсичні речовини, що утворюються в процесі тканинного розпаду пульпи. Потрапляючи в періодонт, ендотоксини призводять до запуску цілого каскаду реакцій на клітинному, мікроциркуляторному, імунному рівнях, наслідком чого є деструкція апікального періодонта і прилеглої до нього кістки $[1,4,6]$.

Тому успіхи чи невдачі в ендодонтії, згідно з сучасним уявленням, зумовлені проведенням якісної дезінфекції кореневих каналів, для чого в даний час запропоновано ряд методів з використанням традиційних та альтернативних факторів впливу на мікрофлору кореневого каналу $[4,5]$.

Серед способів лікування загострення хронічного верхівкового періодонтиту або його гострої стадії часто обирається пасивний, коли кореневий канал залишається відкритим, з метою дренування ексудату із періапікальних тканин. Проте даний спосіб має суттєві недоліки, 
головним 3 яких $є$ масивне інфікування кореневого каналу мікрофлорою 3 ротової порожнини та виникнення стану суперінфекції у порожнині зуба.

Для ефективного лікування стану загострення запального процесу у верхівковому періодонті було обрано спосіб лікування інфікованих ран із використанням препарату «Бетадин». До складу вказаного препарату входить повідон-йод, який має виражену антимікробну дію. Перед застосуванням «Бетадин» змішували 3 кремнієвим сорбентом «Атоксил», для забезпечення пролонгованої дії антисептика та сорбції ексудату у кореневому каналі.

Після механічного і медикаментного опрацювання кореневого каналу, препарат вводили каналонаповнювачем у кореневий канал $\mathrm{i}$ періапікальний простір (по можливості) і залишали у кореневому каналі на турунді під напівгерметичною пов'язкою для дренування вмісту каналу на 1-2 доби. Після зникнення або суттєвого зменшення ознак загострення запального процесу проводили подальше лікування верхівкового періодонтиту згідно обраної схеми.

Вищенаведений метод лікування було застосовано під час лікування 23 хворих на хронічний верхівковий періодонт у стадії загострення. У 16 хворих (69,6 \%) через 1-2 доби відзначилось повне зникнення симптомів загострення, 7 пацієнтів $(30,4 \%)$ відзначили суттєве зменшення болю, набряку та відновлення функції зуба. Вміст кореневого каналу після застосування комбінації «Бетадтн-Атоксил» був вільним від гнійно-некротичних виділень, а подальше герметичне закриття порожнини зуба не супроводжувалось наступним загостренням.

Таким чином запропонований метод дозволяє швидко усунути стан загострення, запобігаючи при цьому вторинному інфікуванню кореневого каналу.

\section{Література:}

1. Клиническая эндодонтия / Лейф Тронстад; Пер. с англ.; Под ред. проф. Т.Ф.Виноградовой. - 2-е изд. - М.: МЕДпресс-информ, 2009. $-288 \mathrm{c}$.

2. Николаев А.И., Цепов Л.М. Практическая терапевтическая стоматология. - М.: «Медпресс-информ», 2003. - 547 с.

3. Педорец А.П., Пиляев А.Г., Педорец Н.А. Предсказуемая эндодонтия. - Донецк.: «Норд-пресс», 2006. - 363 с.

4. Effectiveness of passive ultrasonic irrigation on periapical healing and root canal disinfection: a systematic review. Silva EJNL, Rover G, Belladonna FG, Herrera DR, De-Deus G, da Silva Fidalgo TK. / Br Dent J. 2019. Aug. № 227(3). P. 228-234.

5. Molecular Analysis of the Antibacterial Effects of Photodynamic Therapy in Endodontic Surgery: A Case Series. Vieira GCS, Antunes HS, 
Pérez AR, Gonçalves LS, Antunes FE, Siqueira JF Jr, Rôças IN. / J Endod. 2018. Oct. № 44(10). P. 1593-1597.

6. Persistent extra-radicular bacterial biofilm in endodontically treated human teeth: scanning electron microscopy analysis after apical surgery. Sousa BC, Gomes FA, Ferreira CM, Rocha MMNP, Barros EB, Albuquerque DS. / Microsc Res Tech. 2017. Jun. № 80(6). P. 662-667.

DOI https://doi.org/10.30525/978-9934-26-038-4-37

\title{
ЗНАЧЕНИЕ РИГИДНОСТИ ЭРИТРОЦИТОВ В РАЗВИТИИ МИКРО-АНГИОПАТИИ У БОЛЬНЫХ С САХАНЫМ ДИАБЕТОМ 2 ТИПА
}

\author{
Сморжевський В. И. \\ доктор медицинских наук, \\ профессор кафедры хирургии и трансплантологии \\ Национальная медицинская академия последипломного образования \\ имени П. Л. Шупика, \\ Национальный институт хирургии и трансплантологии \\ имени А. А. Шалимова \\ Манасрах Рашид X. P. \\ аспирант кафедры хирургии и трансплантологии \\ Национальная медицинская академия последипломного образования \\ имени П. Л. Шупика, \\ Национальный институт хирургии и трансплантологии \\ имени А. А. Шалимова \\ Свиридов Н. В. \\ доктор медицинских наук, \\ главный научный сотрудник отдела эндокринной хирургии, \\ заведуюший отделением диабетической стопь \\ Diabetic foot center-Kyiv \\ г. Киев, Украина
}

Реологические параметры (от греч. rhe'os - течение, поток) - это свойства крови, связанные с ее текучестью. Если в крупных сосудах наибольший вклад в движение тока крови вносят инерционные силы, связанные с массой, то в микрососудистом русле на движение тока крови в большей степени влияют ее реологические свойства. Это свя- 